doi:10.7592/TF10.facebook

\title{
Varateismeliste identiteet ja väärtused Facebooki ahelpostitustes $^{1}$
}

\author{
Piret Voolaid
}

Teesid: Artikli keskmes on Eestis üle 450000 kasutaja kogunud suhtlusvõrgustikus Facebook (facebook.com) aastail 2010-2012 kogutud ja peamiselt teismeliste seas levinud ahelpostitused. Umbkaudu 220 tekstist koosneval allikainesel on vormiline ja sisuline ühisosa varasemast traditsioonist tuntud kettkirjadega, kuid keskkond oma etteantud tehnilise struktuuriga võimaldab tekstidel kujuneda omalaadseks facebookilikuks ilminguks.

Kirjutises on esiplaanil küsimused, millised vormilised uuendused on Facebooki keskkonnas kohanenud kettkirjade žanrile ning millised on kirjade temaatilised kategooriad. Epistolaarse kultuuriilmingu analüüs keskendub tekstide sotsiofolkloorsele olemusele, milles esilduvad kommunikatiivsed ja sotsiaalkultuurilised aspektid. Uuritakse, kuidas mõjutab žanri muutumist sotsiokultuuriline ümbrus, millised on eestikeelsete ahelpostituste globaalsed ja lokaalsed mõjutused ning kuidas kajastuvad selles argižanris ajastu realiteedid ja earühmale omased väärtused. Ahelpostitajate kui kindla earühma personaalse ja kollektiivse identiteediloome tasandeid on analüüsitud sotsiaalpsühholoogiast tuntud identiteedi motivatsiooniteooria toel.

Märksõnad: ahelpostitused, Facebook, identiteet, internetifolkloor, kettkirjad, koolipärimus, noortepärimus, sotsiaalvõrgustikud, väärtushinnangud, õnneketid

${ }^{1}$ Artikkel on valminud sihtfinantseeritava teema SF 0030181s08 ning grantide ETF 8149 ja ETF 8137 toetusel. 


\section{Sissejuhatus}

2004. aastal loodud sotsiaalvõrgustik Facebook on viimastel aastatel omandanud nii nooremate kui ka vanemate eestlaste seas suure populaarsuse. Võib väita, et eestikeelses kõnepruugis ka nt näo-, molu-, lõusta-, mordaraamatuks, fesariks või fatšebokiks kutsutud portaal on kujunenud sotsiaalmeedia sünonüümiks. Täiskasvanud võivad sellise keskkonna esmasteks väärtusteks pidada olulisele infole ligipääsu, kuid nooremale, iseäranis kooliealiste põlvkonnale on see eeskätt meelelahutuslik suhtluspaik. ${ }^{2}$ Suheldes tekivad paratamatult omad traditsioonid ning sünnib ja levib mitmesugust folkloori. Käesolev artikkel tugineb killukesele tänapäeva internetifolkloorist - tähelepanu keskmes on ahelsõnumid, mis on postitatud põhiosas 2010. ja 2011. aastal peamiselt ühe tüdrukute sõpruskonna Facebooki seintele. ${ }^{3}$ Sõnumi levitamine on lihtne: postitades sõnumi oma profiili seinale/ajajoonele, jõuab see kohe kasutaja kõikide sõprade uudisvoogudesse, nii et sõprusahela iga liige näeb uusi postitusi oma Facebooki avalehel, saades hea ülevaate sõprade seintest. Niisiis on need postitused olemuselt epistolaarne folklooriilming, mis levib ühe sõrmevajutusega seinalt seinale, moodustades kirja postitajatest inimahela. Sarnaselt tüüpilise kettkirjaga koosneb ahelpostitus sõnumist, milles veendakse adressaati kirja kopeerima ja seejärel teatud hulgale või võimalikult paljudele inimestele edasi saatma. Mõnes mõttes on kogu Facebook üles ehitatud ahelkommunikatsioonile ja -postitamisele, -jagamisele ning ahelpostitusena saab käsitleda ka kõikvõimalike netimeemide (nt pilke- ja pilapildid, nn demotivaatorid) massilist edasisaatmist ja jagamist. Siinses uurimuses jäävad need vaatluse alt kõrvale, kuivõrd edasisaatmise ja jagamise korraldus neis otsesõnu puudub.

Uurimuse siht on anda ülevaade Facebooki ahelkirjadest kui peamiselt teismeliste seas aktiivselt levivast ainesest, analüüsida folkloorsete postituste olemust ja sisulis-temaatilisi väljendusviise

${ }^{2}$ Koolivälise aja veedavad noored tihti arvuti seltsis. 2007. aastal toimunud üle-eestilise koolipärimuse kogumisvõistluse põhjal kasutasid õpilased arvutit keskmiselt 2-4 tundi päevas, kusjuures eelkõige käiakse suhtlusportaalides, millest 2007. aastal olid populaarsemad rate.ee, feim.ee, orkut.ee (Voolaid jt 2007, 358). Facebooki võidukäiku Eesti kasutajaskonna hulgas tähistab aasta 2010 .

${ }^{3}$ 2012. aastal on Facebooki uuenenud profiilirakendusena seina (wall) asemel kasutusel ajajoon (timeline), eesmärgiga muuta kasutaja profill virtuaalseks märkmikuks. 
ning tõlgendada tekste neis kajastuvate identiteediloome ja väärtuste kujundamise mehhanismide kaudu.

\section{Teoreetilisi lähtekohti}

Facebook on infotehnoloogial põhinev uue meedia allvorm. Seesugused sotsiaalvõrgustikud pole pelgalt informatsiooni edastamise kanalid, vaid paigad, mis sarnanevad geomeetrilise kohaga (kus võib toimuda teine elu) ning kohalduvad isegi topoloogilisele või abstraktsele ruumile, st "ma kirjutan oma FB kodulehel", "mul on FB-s ... sõpra" jne (Briggle 2010, 163). Sellel tehnoloogilisel meediapinnal informatsioon elab, kasutajat on informatsioonist raske eristada ning pidevalt toimub aktiivne kommunikatsioon ja uue teadmise loomine.

Igasugune kirjalik tekst sünnib sotsiaalse tegevuse tulemusena (vt nt Kress 2004, 84-105), kusjuures kasutaja valib teadmise vahendamiseks sobiva vormi. Üheks niisuguseks eristuvaks žanriks on Facebooki ahelpostitused. Folkloristlikust vaatepunktist on ahelpostitustel hoomatav ühisosa varasematest aegadest tuntud ahel-, kett- ehk õnnekirjade või õnnekettidega. ${ }^{4}$ Rikkalike juhenditega kristlikku päritolu trükitud kaitsekirjadest ehk nn taevakirjadest leidub Eestis teateid juba 18. sajandi lõpust (Vahtramäe 1998, 181). Folklooriarhiivis talletatud onnnekettidest varaseim pärineb 1883. aastast (Kõiva 1993, 12), niisiis võib Eestis julgelt kõnelda üle saja aasta vanusest kettkirjatraditsioonist. Kohaliku ainese analüütilistes käsitlustes on folkloristid esile toonud ajaloolisi ja liigituslikke aspekte (Anderson 1937; Põldmäe 1938; Kõiva 1993), kuid kirjeldatud on ka žanri arenguid uute tehnoloogiliste keskkondade (arvuti ja internet) lisandudes, lähenedes liigilistele muutustele nt dialoogi mõiste kaudu (nt Seljamaa 2003; 2004; 2005). Interaktiivses keskkonnas, kus tähenduse loomine ja vahendamine on multimodaalne (žanrid pole võrreldes arhiivitekstidega niivõrd

${ }^{4}$ Oletatavasti saksa keelest eesti keelde juurdunud sünonüümsetest terminitest ahel-, kett-, õnnekiri ja õnnekett on ülevaatlikult kirjutanud folklorist Mare Kõiva (1993, 12), põhjalikumalt aga Elo-Hanna Seljamaa oma bakalaureusetöös $(2004,11)$, milles ta nimetab ühtlasi kettkirjade tuumaks või klassikalisteks kettkirjadeks õnne ja õnnetust tõotavaid kirju. Käesolevas uurimuses on avarama tähendushaardega võrdse tasandi sünonüümid ahel- ja kettkiri ning Facebooki keskkonnas täpseim ahelpostitus, mille alaliigiks võib nimetada ka õnnekirja ehk õnneketti. 
lingvistilised kategooriad, arvesse tulevad kõikvõimalikud audio-, visuaal-, tehnoloogilised jne vahendid - vt Kress 2004; Torop 2008 jpt), on uurijal lihtsam jälgida folkloorinähtuste informatiivseid, sotsiaalseid, meelelahutuslikke jmt rolle. Ahelpostituste sisu ja vorm võivad seguneda traditsiooniliste folkloorinähtustega, näiteks tänapäevaste linnalugude, anekdootide ja folkloori lühivormidega, kinnitades veenvalt žanripiiride hägustumist ja klassikaliste folkloorinähtuste kohandumist internetis (vt nt Kõiva, Vesik 2009, 109). Postitused võivad sisaldada didaktilisi narratiive, tõsielu ja folkloori piirimail balansseerivaid hoiatusjutte, mida on leidunud ja kohtab populaarteaduslikus stiilis meditsiinikäsiraamatuis, ohutustehnika, tehnilistes õpetusraamatutes, mitmesugustes eneseabiõpikutes ning mis pedagoogiliste ja kasvatuslike eesmärkidega on varateismeliste earühmale sobiv. Kogu tänapäeva folkloori, sh kettkirjade olulise omadusena on rõhutatud võimet tundlikult reageerida ühiskonnas toimuvatele sündmustele ja peegeldada neid omal moel (Hoppál 2000, 330). Folkloori, mis sõltub meedia loodud teadmisest aktuaalsete päevasündmuste kohta ja kommenteerib neid, on nimetatud ka uudis(folk)looriks (nt Frank 2011). Uudisfolkloor võib väljendust leida väga paljudes folkloorivormides, nagu nt naljad (sh katastroofihuumor), linnamuistendid, digitaalselt töödeldud fotod, pilavad uudislood, trükiste vahesedelid, mitteametlikud ringkirjad, laulu- ja luuleparoodiad, kommerts- ja poliitreklaamid, koomiksid ja animatsioonid. Ka Facebooki ahelpostitus omandab uudisfolkloori väärtuse, kui ammutab ainest päriselt aset leidnud (traagilistest) päevasündmustest ning reageerib nii meedias kajastatud sündmusele kui ka meediakajastustele endile. Kogu netifolkloori tuleb vaadelda globaalsel tasandil, nii on ka eesti ahelpostitustes märke tihedast kultuurivahetusest (sh tõlked ühest kultuurist teise, keelte segunemine), mis viitab kaugkommunikatsiooni osakaalu suurenemisele tänapäeval.

Facebooki ahelpostitusi võib nimetada epistolaarseks pärimusžanriks, mida sotsioloog Liz Stanley järgi iseloomustab nende dialoogilisus, suunatus minast erinevale "teisele" (Stanley 2004, 202-203)5. Ahelsõnum pole Facebooki keskkonnas privaatne, see võib olla pos-

${ }^{5}$ Siinkohal on oluline märkida, et dialoogi ideed (Mihhail Bahtini võtmes) väga laial tähendusväljal on kettkirjade kui dünaamilise folkloorižanri põhjalikul käsitlemisel kasutanud Elo-Hanna Seljamaa (2004). Tulipunktis on ennekõike uurija dialoog empiirikaga, aga ka suhestumine teiste uurimustega. 
titatud konkreetse indiviidi profiilile ehk konkreetses keskkonnas seinale (uuemas versioonis ajajoonele), kuid on nähtav paljudele. Enamasti ongi see orienteeritud impersonaalsele ainsuslikule "teisele”, pidades samal ajal silmas ka laiemat kogukonda. Sõltuvalt adressaatide reageeringust - kas sõnum kopeeritakse üksühele ja saadetakse edasi, kasutaja teeb sellesse muudatused, postitatud sõnumit kommenteeritakse või piirdub reageering meeldib-nupu vajutamisega, sõnumi läbi- või ülelugemisega - moodustub aktiivne või passiivne kommunikatsioon. Teise olulise omadusena nimetab Stanley kirjade perspektiivsust, nende struktuur ja sisu muutuvad vastavalt individuaalsele saajale ja aja möödumisele (Stanley 2004, 202-203). Facebooki keskkonnas leiduvad ahelpostitused lõpevad kõige tavapärasemalt imperatiivse vormeliga, nt "Pane like ja postita oma seinale!" või "Lisa see enda staatusesse", nõudes niisiis sõnumi kopeerimist ja levitamist. Kolmandaks on kirjadel tugevalt arenevad konventsioonid ja mõttesuunad, omaette epistolaarne eetika. Kõik need aspektid võivad muutuda vastavalt konkreetsetele kirjavahetustele ja ajalistele parameetritele. Samas ei ole need omadused ainuiseloomulikud kirjale kui žanrile, vaid kirjeldavad sotsiaalset interaktsiooni üldisemalt. Kogu nähtust kindlatele kaanonitele allutada on keeruline, pigem saab seda mõtestada avatud, intertekstuaalse, loova, dünaamilise kontekstikeskse ilminguna, mis langeb kokku mitmete folkloori žanriteoreetiliste vaatekohtadega (Briggs, Bauman 1992; Bauman 1992; Ben-Amos 1997 jpt).

Noorukite internetikasutuse uurijad on kinnitanud, et noorte online- ja offline-maailmad on psühholoogiliselt seotud ja uusi tehnoloogiavorme kasutatakse oluliste arenguvajaduste, st seksuaalsuse, läheduse, suureneva iseseisvuse ja identiteediotsingute teenistuses (vt Reich jt 2012, 357). Ka noorte seas leviva folkloori üks eesmärke on toetada ealiste vajaduste täitmist. Ainese analüüsimisel laiemalt on sageli leitud tuge identiteediuuringutest, mille peamine eesmärk on välja selgitada, kuidas toimub pärimuse abil individuaalse või kollektiivse enesekontseptsiooni konstrueerimine, argumenteerimine või kaitsmine (vt nt Kuutma 2006). Eesti folkloristid on viimasel kümnendil keskendunud identiteedile väga mitmekülgselt, relevantsemad sellealased pidemõisted on uurimustes olnud nt etniline identiteet ( $\mathrm{nt}$ Korb 2012; Valk, Ojamaa 2011), kohalik identiteet (nt Kalda 2004), sooline identiteet (nt Ehin 2003; Kalmre 2010) jne. Eda Kalmre (2010) on tüdrukute eneseesitlust analüüsinud suhtlusportaali rate.ee näitel, sentimentaalsed proosavormis 
armastusjutu(stuse)d on olulised tüdrukute eneseväljenduses ja identiteediloomes, paljuski samu funktsioone täidavad tundelised ahelkirjad. Ka vaatlusalused Facebooki ahelpostitused on enamasti konkreetse earühma pärimus - aktiivne harrastajaskond on peamiselt varateismelised vanuses 10-12 aastat ${ }^{6}-$, mis toetab sihtrühma sotsiaalse identiteedi kujundamist.

Sotsiaalpsühholoog Vivian L. Vignoles jt (2006, 311-312) on eri vanuses inimeste identiteedi loomist ja hoidmist selgitanud motivatsiooniteooria toel. Identiteediloomele avaldavad mõju kuus põhimotiivi - enesehinnang (self-esteem) ehk enese väärtuste mõõdupuu, järjekestvus (continuity) ehk püsimine sama inimesena eri situatsioonides, eristumine (distinctiveness), kuuluvus (belonging), enesetõhusus (efficacy) ja tähendus (meaning) -, mis on ühtlasi seotud vajadustega, mida inimene identiteeti luues ja tajudes rahuldab. Käesolevas uurimuses on asjakohane esitada küsimus, kas ja kuidas aitab ahelsõnumite postitamise ja kommenteerimise traditsioon rahuldada identiteediloomega seotud vajadusi, millised motiivikategooriad (nt enesehinnangu tõstmise vajaduse, kuuluvusvajaduse rahuldamine) on selles traditsioonis esiplaanil ja kuidas väljenduvad need kategooriad tekstide kaudu.

Sotsiaalpsühholoogiliste võtete rakendamine on õigustatud selle osa ahelpostituste analüüsimisel, mis viitab rühmasisestele suhetele ja rollidele ning mida saab tõlgendada sotsiaalse identiteedi mõiste kaudu. Sotsiaalse identiteedi teooria järgi (nt Tajfel 1978, 1981; Valk 2003) on tegu selle osaga indiviidi minakontseptsioonist, mis põhineb tema teadmisel kuulumise kohta sotsiaalse(te)sse rühma(desse). Kollektiivse suhtluse aluseks on inimese vajadus kinnitava ja eristatava identiteedi järele, millel põhineb inimese emotsionaalne enesehinnang ja enda väärtuslikkuse tunnetamine. Õpilaste sotsiaalse staatuse hindamiseks on kasutusel peamiselt sotsiomeetrilise nominatsiooni meetod ning kaaslaste hindamise meetod (Tropp, Saat 2010, 70). Sõprussuhetele suunatud ahelpostitust koos kommentaariumiga võib vaadelda informaalse sotsiomeetrilise vahendina, millega ärgitatakse sõpruskonna liikmeid enda suhtes mitmesuguseid (nii positiivseid, neutraalseid kui ka negatiivseid) valikuid tegema ning hinnatakse ise samadel alustel teisi.

${ }^{6}$ Facebooki reeglite järgi peavad võrgustiku kasutajad olema vähemalt 13aastased, kuid väga paljud nooremad nii Eestis kui ka mujal märgivad ennast konto registreerimisel vanemaks. 


\section{Aines ja analüüs}

Käesolevas uurimuses analüüsitavate ahelpostituste koguhulk on 220 tekstitüüpi, need on kogutud asünkroonilise internetisuhtluse jälgimise teel. Facebooki kasutajana (siinses uurimuses eeskätt lapsevanemana) olen kogunud oma (eeskätt eelteismeliste ja teismeliste) sõpruskonnaliikmete endi või nende seintele postitatud kettsõnumeid. ${ }^{7}$ Sotsiaalsete situatsioonide fikseerimisel olen enamasti jäänud passiivseks jälgijaks, kuid mõnikord ka lisaküsimusi esitanud.

Sõpruskonna liikmetest moodustub poolprivaatne foorum, millele on ligipääs ainult keskkonnas registreeritud ja sõpruskonda kuuluvatele liikmetele. Keskmiselt on igal liikmel paarsada sõpra, kellest mõnega pole reaalelus iialgi silmast silma kohtutud. ${ }^{8}$ On selge, et sellises plaanis on sõbra mõiste laienenud ja teisenenud, FB-sõprade arvust võib sõltuda teismelise enesehinnang ja sellest on ajendatud ka nn Facebooki uusvanasõna: Ärgu olgu sul 777 euri, vaid 777 sõpra. Kõige aktiivsemad kettkirjade postitajad tunduvad olevat 10-12aastased tüdrukud, kes on ilmselt teistest julgemad oma tundeid välja näitama ning kellele on kettkirjade temaatika (sõprus, romantilised tunded, pere, kodu) ja sentimentaalne laad ealiselt olulised. Samasugust tendentsi näitavad 1992. aastal korraldatud üle-eestilise koolipärimuse kogumisvõistluse tulemused, umbes 10aastaste õpilaste saadetistes leidus kettkirju enim (vt ka Kõiva 1993, 13). Samal temaatikal on kindel koht koolitüdrukute salmiku-ja (sala)kaustikukultuuris, aga ka 2000. aastatel eesti noorte hulgas populaarsetes suhtlusportaalides, nt rate.ee, orkut.com. ${ }^{9}$ Ahelsõnumite postitamisel on märgatav sooline aspekt: Facebooki sõpruskonda kuuluvad poisid näevad küll kõiki ahelsõnumeid, kuid saadavad ise kirju edasi harva. Kui poisid seda teevadki, siis lähevad kaasa pigem irooniliste ja parodeerivate kirjade saatmise

${ }^{7}$ Ahelpostitused originaalkujul asuvad autori valduses, suurem osa tekstikogust on avaldatud populaarväljaandes "Pane like ja postita oma seinale: Valimik Facebooki ahelpostitusi" (Voolaid 2012).

8 2012. aasta oktoobris toimunud koolipärimuse välitööd Hiiumaal näitasid, et Facebooki sõbrad, kellega virtuaalselt enim suheldakse, langevad olulisel määral kokku nendega, kellega sagedamini ka silmast silma suheldakse (nt klassi- ja koolikaaslased).

${ }^{9}$ Orkut.com ja rate.ee olid noorte hulgas levinumad sotsiaalvorrgustikud 2007. aastal toimunud üle-eestilise koolipärimuse kogumisvõistluse tulemuste põhjal. 
lainega, mille siht on tõsimeelseid ja tundelisi ahelsõnumeid naeruvääristada, äraspidi pöörata ja tüdrukute postituste järgsetes kommentaariumites rämpsuks tituleerida. Siinkohal ongi oluline märkida, et kuigi Facebooki süsteem soosib nii enda kui ka teiste seintele postitamist, on seesugustel ahelpostitustel funktsionaalne ühisosa rämpspostituste ehk spämmiga, mida saadetakse edasi ilma seinaomaniku soovita ning mis võib osutuda petukirjaks, kahjustades halvimal juhul selle tõsiuskset vastuvõtjat nt arvutiviiruse või ainelise kahjuga. Sotsioloogilisest vaatepunktist on spämmi peetud huvitavaks reaktsiooni poolest, mida ta kutsub esile interneti ja arvutivahendatud kommunikatsiooni kauastes kasutajates. Spämmimist seostatakse üsna sageli virtuaalruumi uustulnukatega, kes pälvivad vanade kasutajate pahakspanu, sest nad ei tea või ei austa vaikimisi määratletud reegleid (Bell jt 2004, 165). Kettkirjade postitamisel saab täheldada teatavaid paralleele - kindlasti on 10-12aastased uljamad kirjade edasisaatjad nii oma nooruse tõttu (kirjad tunduvad neile värsked ja huvitavad, nad on teemadest rohkem mõjutatud, ka usuvad enam nende sisu) kui ka teadmatusest reeglite ja tavade kohta.

\section{Facebooki kettkirjade temaatiline liigendus}

Facebooki ahelpostitused on väga eriilmelised nii tekstide pikkuselt (ühelauselistest pikemasüžeeliste lugudeni) kui ka neis leiduvate teemade ja funktsioonide poolest. Varasemat kettkirjatraditsiooni on püütud allutada väga erinevatele liigitussüsteemidele (nt VanArsdale 2007; Seljamaa 2003; Krikščiūnas 2012). Facebooki kettkirjadest ülevaatlikuma pildi saamiseks olen liigitanud tekstid järgmisteks sisukategooriateks: sõbrad ja sõprussuhted; pere ja kodu (lähedased); koolis toimuv, õppimisega seonduv; tõsielusündmuste järgsed ahelpostitused; õnnetuse ärahoidmine (elu ja tervise väärtustamine, sh alkoholi ja narkootikumide eest hoiatamine); loomadest hoolimine; kalendritähtpäevadega seonduvad ahelpostitused; tähelepanuülesanded ja testid; ahelkirjaparoodiad. Nagu folkloristlike liigitamiskatsete korral tavaline, võivad ka ahelpostituste kategooriapiirid olla hägusad, nt sõprussuhetest kõnelev tekst võib ühtlasi olla seotud koolieluga. 
Tabel 1. Facebooki kettkirjade (221 tü̈̈pi ehk samasisuliste variantide kogumit) temaatilised kategooriad.

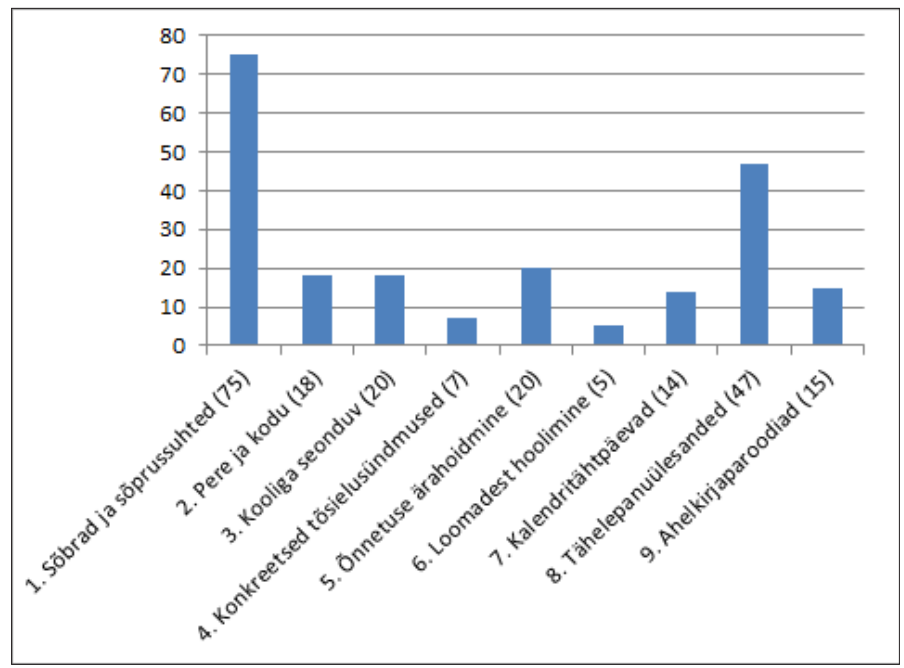

\section{Sõbrad ja sõprussuhted, personaalse ja sotsiaalse identiteedi otsingud}

Eriilmelised ahelpostitused saab jagada temaatilistesse rubriikidesse. Eelteismeliste ja teismeliste elus hõlmavad väga olulise koha eakaaslased ja nendega läbisaamine, varasemast tähtsamaks kujuneb vanemate kontrolli vähenemine, enda sotsiaalne positsioneerimine. Nii pole midagi imelikku, et kõige rohkem teismeliste ahelpostitusi on pühendatud sõprusele ja suhetele, kutsutakse üles väärtustama tõelist sõpra, testitakse sõprussidemete tugevust ja oma positsiooni sõpruskonnas. Ühest küljest peegeldavad seesugused tekstid sotsiaalse identiteedi otsinguid, neis kajastuvad sotsiaalsed suhted ja kuulumine sotsiaalsetesse rühmadesse, need on seotud omavaheliste võimusuhetega pärimusrühmas. Nõnda võivad testivad ahelpostitused oma vastustega rahuldada noorte kuuluvusvajadust ja suhestumist, mis on uurijate (nt Vignoles jt 2006; Deci, Ryan 2008, 183) järgi enesemääratlemise põhivajadus. Kuuluvusvajadusele tuleb pidevalt otsida tõestust kõikvõimalike suhtekontaktide abil. 
Teisest küljest toetavad need noore isikliku identiteedi (minapildi või enesekontseptsiooni) kujunemist. Alljärgnev postitus näiteks võimaldab kujunemisjärgus teismelisel sõpruskonna liikmete kaudu enda iseloomuomadustele kinnitust saada ja tajuda kaaslaste suhtumisi.

Pane see enda staatusesse ja saa teada, mida inimesed sinust arvavad: 1. Hull. 2. Ma tahaks sulle musi teha. 3. Hüperaktiivne. 4. Jobu. 5. Ma igatsen sind. 6. Parim sõber. 7. Kena. 8. Tark. 9. Loll. 10. Ma tahaks sinuga deitima minna. 11. Mugav. 12. Kuum. 13. Naljakas. 14. Kallistaja. 15. Vapustav. 16. Mõtlik. 17. Armas. 18. Ilus. 19. Kõva häälega. 20. Lahe. 21. Ma armastan sind. Mitu võib ka. ;)

Ettekujutus enesest saadakse läbi peegelduse inimestelt, kes on teismelise silmis olulised. Testi formaadis ahelpostituse abiga on noorel endal seda peegeldust sotsiaalvõrgustikus lihtne korraldada. Mõnes nn sotsiomeetrilise testina toimivas ahelpostituses on sõpradelt soovitud vastused protsenditäpsusega määratletavad.

10\% - halb sõber, $20 \%$ - pole ammu suhelnud, 30\% - kahju, et tülis (); 40\% - rumal, 50\% - normaalne, 60\% - lahe tü̈̈p, 70\% - nalja saab $\odot$, , 80\% - hull!, 90\% - sitaks hea sõber :D, 95\% - parim sõber!, 97\% - meeldid mulle (); 98\% - hakkame käima?, 100\% - armastan sind! Kopi see ka oma seinale, et vaadata, mis sinu sõber sinu kohta valib! $\odot$

Seda tüüpi ahelpostitusi kommenteeritakse enim, sest neis ärgitatakse sõpruskonna liikmeid enda suhtes (nii positiivseid kui ka negatiivseid) hinnanguid andma stiilis Kui olen best, siis kirjuta B, kui olen lihtsalt sõber, siis kirjuta $S$, kui vihkad mind, siis kirjuta $V$, kui tahad, et jääme igavesti sõpradeks, siis kirjuta FF. Nii püütakse välja selgitada oma meeldivuse määr ja hinnatakse ühtlasi ise teisi. Kuid tekstidest ilmneb ka, et mõnikord on need üles ehitatud pigem positiivse hinnangu kujundamisele, etteantud omadused on ainult positiivsed või on neis heakskiitu väärivad ülekaalus ja kommentaarid on üldiselt kiitvad. Mõnikord kasutatakse selliseid postitusi omavaheliste suhete tundmaõppimiseks, nende kaudu võivad ilmneda sotsiaalse rühma liidrid ja tõrjutud. Just seesugused postitused toetavad kujunemiseas noorte identiteediloomet, mille peamiseks motivaatoriks on (vt eespool Vignoles jt 2006) enesehinnangu, kuuluvustunde, enesetõhususega seotud vajaduste rahuldamine.

Facebooki süsteemile omased nupud "meeldib", "kommenteeri" ja "jaga" võimaldavad sõpradel postitustele vastata ja ühtlasi saa- 
da sõpruskonna liikmetelt tagasisidet konkreetse postituse kohta. Sentimentaalsest ahelkirjast saab omamoodi meedium, mille kaudu väljendatakse sõbratundeid, näidatakse hoolimist, kuid võidakse mõni liige ka rühmast tõrjuda. Nii mõneski postituses tulevad ääriveeri või otseselt jutuks poiste ja tüdrukute tundelised suhted ning armastus, mis on teismeliste soolisel enesemääratlemisel ja täiskasvanuks küpsemisel möödapääsmatu. Teema võib olla lahendatud pikkade ja traagiliste armastuslugudega, nagu nt järgmine postitus:

Mis tähtsust on armastusel?

Tüdruk ja poiss sõidavad kiirusega $160 \mathrm{~km} / \mathrm{h}$. Tüdruk: Pidurda, ma kardan. Poiss: Ei see on lõbus! Tüdruk: Ei ole. Palun, me sõidame liiga kiiresti. Poiss: Ok. Ütle, et sa armastad mind ja ma võtan hoogu maha. Tüdruk: Hea küll. Ma armastan sind. Nü̈̈d pidurda ... Poiss: Nü̈d palun kallista mind. *Tüdruk kallistab poissi* Poiss: Kas sa saad $m$... u kiivri ära võtta ja ... endale pähe panna? See ajab mu hulluks. Järgmise päeva lehes: Mootorrattur sõitis hoonesse pidurivea tõttu, noormees suri, kaaslane jäi ellu. Tegelikult mõistis poiss poolel teel, et pidurid ei tööta, selle asemel, et tüdrukule sellest rääkida, palus ta tüdrukul öelda, et armastab teda ja tundis ta kallistust viimast korda ... Poiss andis oma kiivri tüdrukule, hoolimata sellest, et see tähendas ta surma ... พఛఛ Kui ka sina armastad kedagi, siis postita see oma seinale.

Seesugune nimetute tegelastega terviklike dramaatiliste lugude kasutamine on ahelpostitustes väga levinud. Ootamatu puänt on emotsionaalselt meeldejääv ja võib mõjuda pedagoogiliselt.

Uudsete ahelpostituste hulgas on üksjagu ankeetvormis tekste, mis ei ole enam anonüümsed, vaid kaasavad sõpruskonna liikmeid nimeliselt. Paljud postitused on intrigeerivad ja simuleerivad keelatud/varjatud maailma, kuhu kuuluvad alkohol, seks ja muu temaatika, millega postitajatel endil praktilised kogemused selles eas veel puuduvad, kuid huvi nn täiskasvanute teemade vastu on loomulikult olemas.

Sünnipäev! Mine oma profillile ja võta vasakult esimesed kaheksa sõpra:

Sünnipäevalaps: ...

Jääb laua alla magama: ...

Hüppab tordi sisse: ...

Kaanib omale viina sisse: ...

Teeb laua peal strippi: ...

Tantsib omaette: ... 
Suudleb sünnipäevalast: ...

Tuleb kutsumata peole ja joob end täis: ...

Palju õnnnnne! :D

Varateismelisele pakub selline sünnipäevapeoankeet võimaluse arendada piire kompavat fantaasiamaailma. Kõnealune peokultuur võib olla täiskasvanutele reaalsus, kuid pakub noorele pigem loovat võimalust paotada ust täiskasvanute salapärastesse tegemistesse. Vaieldamatult mõjutavad seesugust temaatikat tänapäeva meedia ja televisioon.

Kogu hilistekkelisel pärimusel on tihedad sidemed popkultuuriga. Popkultuuri, reklaami, meedia mõju noorte maailmale, sh huvi filmide, muusika ja spordi vastu kinnitavad postitustes ankurdunud kohalikud ja piiritagused noorteiidolid (nt Koit Toome, Getter Jaani, Justin Bieber, Rihanna jpt), Harry Potteri lugudest tuntud tegelaskujud ja nendega seonduv jne.

Mine oma profililile ja vaata vasakule, need kümme sõpra on:

Lady Gaga: ... :D

Michael Jackson: ... :D

Madonna: ...: :P

Selena Gomez: ...

Rebecca Black: ... :P

Miley Cyrus: ... $x D$

Justin Bieber: ... oimaeisaa $x) x$ )

Usher: ... :D

Rihanna: ... :P

Bruno Mars: ... :D

Postitusi kommenteerivad põhiliselt need sõpruskonna liikmed, kelle nimed postitusse sattusid. Tegevus, millega nt sünnipäeval hakkama saadakse, võib olla intrigeeriv, kommentaarid on tavaliselt humoorikad ja lubavad postituses algatatud tegevuste või tegelaste pinnalt edasi fantaseerida, konkreetset tegevust ümber lükata või seda hoopis utreerida.

\section{Lähedased (perekond ja kodu)}

Omaette allteema moodustavad pereliikmete ja koduga seotud postitused, mis kinnitavad perekonna, sh vanemate, vanavanemate ja teiste lähedaste (nt õde, vend, tütar, poeg) kaalukust noorte elus. Neis näidatakse üles hoolimist oma ema-isa vastu ja pole juhus, 
et sedalaadi kettkirju postitatakse puhanguliselt emadepäeval ja isadepäeval, aga ka muul ajal. Pereliikmetega ahelpostitused kinnitavad mitmete uuringute (nt Harter 1999) tulemusi, et teismeeas muutuvad eakaaslaste arvamused varasemaga võrreldes üha olulisemaks, kuid vanemate ja lähedaste tähtsus püsib sõpruskonna kõrval endiselt suur ega vähene. ${ }^{10}$

Mõnikord tuletatakse neis kas otse või mõistu meelde vanemate tegematajätmisi ning manitsetakse ema-isa langetama lapsest hoolivaid valikuid ja hindama moraalseid väärtusi. Just niisugust ideed väljendab alljärgnev allegooriline narratiiv, milles poeg üritab isale märku anda, et tööst olulisem peaks olema lapsele pühendatud aeg.

Isa saabus hilisõhtul töölt koju. Ta oli väsinud ja pahur nagu alati. Ukselävel ootas teda viieaastane poeg: "Isa, kas võib sinult midagi küsida?"

"Loomulikult, aga mis lahti on?"

"Isa, kui palju sa tunnis teenid?"

"Miks sa seda teada tahad?" ärritus isa.

"Mul on vaja. Palun ütle, kui palju sa tunnis teenid?"

"Noh, viiesaja ringis. Aga mis siis?"

"Isa, kas sa saad mulle laenata kolmsada krooni?"

"Sa tahad raha mingi tobeda mänguasja jaoks, jah?" tõstis isa häält. "Mine oma tuppa ja heida magama! Ei tohi olla selline egoist! Mina töötan terve päeva, tulen koju rampväsinuna ja sina hakkad esitama oma nõudmisi!"

Poeg läks vaikselt oma tuppa ja sulges ukse. Isa oli ikka veel pahur. "Alguses küsib mu palga järele ja siis tahab veel raha!" Mõne aja pärast isa rahunes ja tal hakkas poisist kahju. "Võib-olla on tal tõesti midagi väga vaja? Tühja sellest kolmest sajalisest, ta ei ole ju kunagi minult raha küsinud."

Kui isa poja tuppa läks, oli too juba voodis.

"Kas sa magad juba?" küsis isa.

"Ei, lihtsalt laman," vastas poiss.

"Ma vist olin sinuga liiga karm. Mul oli täna raske päev. Anna mulle andeks! Siin on raha, mida sa palusid."

Poiss tänas rõõmsalt ja võttis padja alt välja mitu kulunud kupü̈ri. Kui isa nägi, et pojal on raha, kihvatas tal jälle. Poiss luges kogu raha hoolikalt üle.

${ }^{10}$ Väidet kinnitavad ka 2007. aastal toimunud üle-eestilise koolipärimuse kogumisvõistluse tulemused. Küsitluskava esimese teema "Vaba aeg ja sõbrad" juures paluti õpilastel nimetada oma eeskujusid. Tuntud lemmikmuusikute, -näitlejate, -lauljate ja -sportlaste kõrval nimetati väga sageli oma vanemaid (mis näitab, kui oluline roll on noorte elus nende endi hinnangul perekonnal, vt ka Voolaid jt 2007, 356). 
"Miks sa minult raha küsisid, kui sul juba on raha?" porises isa.

"Mul jäi puudu, aga nüüd tuleb täpselt välja," vastas poeg. "Näed, siin on täpselt 500 krooni. Tahaksin osta tunni sinu aega. Palun tule homme töölt tund aega varem koju ja sööme koos õhtust."

Kui arvad, et kõige väärtuslikum on aeg, mille veedame oma kallite inimestega, pane like ja postita see mõistulugu ka enda seinale!

Kultuurilistele ja ühiskondlikele muutustele võivad viidata pealtnäha pisidetailid, tekstis esinev rahaühik kroon võimaldab dateerida mõistujutu levikuajana krooniaja, mis lõppes 31. detsembril 2010.

Siinse kategooria postitustes ilmnevad hoolivus, headus, ausus, peale ema-isa on esiplaanil teisedki lähisugulased, nt järgnevas postituses väljendatakse armastust vennale-õele:

Mu sõber küsis, kas ma armastan oma venda /õde. Ma vastasin ei. Siis küsis ta, kas ma läheksin talle ta muredes appi, ma vastasin ei. Siis lõpuks küsis, kas ma üldse hoolin oma vennast/oest? Mina vastasin: "Ma ei armasta oma venda /õde, vaid ma jumaldan teda, ma ei läheks ainult muredes appi, vaid ma jookseksin talle järele ka põlevasse majja, kui ta seal oleks, ja kui teda enam seal poleks, siis sureks." Pane like ja kopeeri see postitus oma seinale, kui sul on maailma parim venna /õde! :)

Olen esimese ja teise kategooria eristanud, kuid mõlemale omane moraal, millega väljendatakse sõpruse ja ligimesearmastuse tähtsust, võimaldab neid vaadelda ka koondkategooriana (abstraktne ligimesearmastus ja inimelu ajutisus eristuva kategooriana vt nt Seljamaa 2003).

\section{Kool ja koolis toimuv}

Kolmas teema haakub mõneti esimesega, kuid on siiski rohkem seotud kooli ja koolis toimuvaga. Sõnumites peegelduvad kooliga seotud positiivsed tahud, mis väljenduvad kooliootuses ja suhtumises kooli ja koolikaaslastesse kui millessegi meelepärasesse, nt

Mulle väga meeldib minu klass. Kui sulle ka meeldib oma klass väga ja sa tahaksid seda näha, pane like ja postita see enda seinale (L)

Teisalt aga kajastavad need läbi huumoriprisma kooli ja õppimisega kaasnevaid painavaid kohustusi:

Miks peab koolis käima? Matemaatika - meil on ju kalkulaator. Emakeel - ma oskan rääkida. Fü̈̈sika/keemia - jajah, päike on 
kuum. Bioloogia - ma tõesti tean, et jänesel on kõrvad. Terviseõpetus - oskan kõndida ja joosta, kui peab. Geograafia - põhi, ida, lõuna, lääs. Ajalugu - tean, mis eile juhtus. Postita see enda seinale, kui oled sama meelt! (:

Vaatlusalune pärimusrühm on küll varateismelised, kuid ahelkirju postitavad ka täiskasvanud. 2012. aasta septembri esimestel päevadel käivitasid just täiskasvanud koolialgusega seotud ahelüleskutse, mis osutab selle folkloorižanri pedagoogilistele võimalustele. Täiskasvanud ja lapsevanemad on Facebookis sõpruskonna kaudu lastega ühenduses, ahelpostituse vormi kasutatakse konkreetsel juhul pedagoogilistel eesmärkidel, õigete käitumisjuhiste meeldetuletamiseks.

Kõigile lastele ja noortele, kes naasevad kooli!

Kui näed, et kellelgi on raske leida sõpru või näed kedagi kiusatavat, kuna neil pole sõpru või kuna nad on liiga arglikud või ei ole just kõige peenemates rõivastes, siis ole hea ja toeta neid. Tervita või vähemalt naerata neile koridoris või kooliõuel. Sa ei tea, milline on tema elu väljaspool kooli. Sinu sõbralikkus võib muuta kõvasti kellegi elu!

Kopeeri see oma seinale, et lõpetada koolikiusamine.

Laiemalt võttes viitab see koolikiusamisest kõnelev postitus ühiste väärtushinnangute kujundamisele, postitusele järgnenud täiskasvanu kommentaar (nt Tähtis jutt. Kehtib ka õpetajate puhul ja suurte inimeste töökohtades) annab probleemile avarama ühiskondliku mõõtme ja viitab, et kiusamine ja võimupositsioonide kurjasti kasutamine ei pruugi olla seotud ainult kooli ja koolinoortega, vaid ühiskonnas märksa laiemini levinud. Omaette põnev teema ongi tekstide autorlus: postitusi lugedes võib oletada, et pedagoogiliste ja keerukama ülesehitusega mõistujuttude loojad on täiskasvanud, kelle tekste noored tarbivad ja kellelt suunavad väärtused pärinevad.

\section{Uudis(folk)loorina levivad ahelpostitused}

Paljude ahelpostituste mõistmiseks tuleb küsida, mis toimus mõne konkreetse kirja leviku ajal ühiskonnas või millised sündmused olid parajasti meedia ja avalikkuse erilise tähelepanu all. Nii mõnegi postituse leviku on käivitanud ühiskonda ja avalikkust laiemalt puudutanud päriselt aset leidnud olukorrad, päevakajalised sündmused ja vapustused ning nende kajastused meedias. Kettkirjad 
võivad peegeldada ümbritseva reaalsusega seotud ja konkreetsetest elusündmustest ajendatud emotsioone, hirme. Nii ilmneb ahelpostitustest inimlik oud ja mure, mis on seotud näiteks 2011. aasta juulikuus Norras Utøya saarel toimunud veretöö ja selle toime pannud kurjategija karistamatusega.

Inimene, kes tappis Oslos vähemalt 92 inimest, võib saada kõige rohkem 21 aastat vangistust. Lisa see oma seinale, kui sinu meelest peaks ta saama eluaegse vangistuse või surmanuhtluse.

Teavet sündmuse kohta saadakse peamiselt meediauudiste vahendusel, ahelpostitused on reaktsiooniks nii sündmustele endile kui ka sündmuste meediakajastustele. Meedia kaudu jõuavad Eesti teismeliseni üleilmsed ja kauged juhtumid, aga ka lokaalspetsiifilised sündmused. Kaasatust Eesti ühiskonna kitsaskohtadesse näitab 2011. aasta sügisel uudisfolkloorina levinud postitus, mis levis pärast ühe Tallinna lasteaialapsega juhtunud onnnetust ning milles kutsuti linnavalitsejaid üles mõtlema laste turvalisusele ja mänguväljakuid korda tegema.

Eile kell 12 sai surma sü̈tu kolmeaastane poiss LASNAMÄE LASTEAIAS!!!! Põhjuseks oli redel, millel oli puudu üks redelitoru. Poiss jäi sinna kinni ja lämbus. Meedikud pü̈̈dsid teda elustada, kuid asjatult. Miks ei võiks linn teha lasteaia mänguväljakud korda? Miks poliitikud tõstavad ainult oma palka? Miks nad ei võiks panna seda raha hoopis laste mänguväljakutele? Kui sa oled poolt, et linn võiks lasteaia mänguväljakud korda teha, kliki like ja postita see teade oma seinale. :/ /

Sellised ahelnarratiivid sisaldavad sageli stereotüüpe (nt stiilis poliitikud tõstavad ainult oma palka), mille kaudu toimub üldisemate kollektiivsete identiteetide omandamine ja töötlemine.

\section{5. Õnnetuse ärahoidmine (sh arvutiviiruste, alkoholi, narkootikumidega seonduv)}

Mõnikord on ahelpostitustele omane ähvardav toon, mis võib ka ise hirmu põhjustada. Õieti on see klassikaline kettkirja omadus - kirja edasisaatjale lubatakse õnne ja head ning käsu eirajat ähvardatakse õnnetuse ja tagajärgedega stiilis, kes teatud aja jooksul ei jõua postitust kopeerida ega edasi saata, sellega "juhtub midagi väga hullu". Usulise elemendiga taevakirjade leviku taandumist võis täheldada 
juba pärast Esimest maailmasõda (vt nt Anderson 1937, 23), kuid kettkirjamaailmale omane ebausk ja maagiataotlus (veendumus, et ettekirjutatud moel tegutsemise ja kirja levitamisega võib ise oma elu kontrollida ja edu tagada) pole tänapäevalgi päris kadunud. Lühiküsitlused võimaldavad väita, et just nooremad postitajad usuvad kirja sisu. ${ }^{11}$ Samas on nüüdisajal varasemast olulisem kirjade roll omavahelises suhtlemises, eriti kui tehnilised lahendused võimaldavad kirju kommenteerida ja nende kohta arvamust avaldada.

Siintoodud ainese hulgas leidub ka tõsiseid hoiatusi. Kettkirjadega hoiatatakse üksteist näiteks arvutiviiruste eest, ent pole teada, kas ja kuivõrd kasutajad tekstis nimetatud (üksjagu kentsakat nime kandvate) viirustega päriselt kokku on puutunud.

Facebookis levib viirus troojalane, mille nimi on Koobface uss. See varastab sinu infot, tungib süsteemi ja sulgeb selle. Ära ava linki Barack Obama Clinton Skandal. Ja kui Smartgirl 15 saadab sõbrakutse, siis ära vasta sellele, see on VIIRUS. Kui keegi sinu sõpradest peaks sellele vastama siis saad viiruse ka sina. PANE SEE POSTITUS OMA SEINALE JA LEVITA SÕPRADE SEAS!!!!!!

Samuti tuletatakse meelde halbu harjumusi - näiteks, et noored ei istuks alkoholi tarbinult autorooli ega laseks ka purjus kaaslasel seda teha. Hoiatavate ahelkirjade süžeed võivad olla sageli laenatud varemtuntud linnalugudest. Seesugused pikemad, tihtipeale moraliseerivad mõistukirjad meenutavad praktilisi hoiatusi ja mõjuvad kui ärahoidvad meeldetuletused ja ennetavad abinõud, mis nooruse uljuses võivad meelest minna. Alljärgnev postitus on alkoholi süül juhtunud autoavariis hukkunud tüdruku kahetsev pöördumine ema poole - väga emotsionaalse memoraadisugemetega kirjutise eesmärk on noort kas või korraks mõtlema panna ja hoiatada mõtlematute tagajärgede eest.

Ema, ma läksin oma sõpradega peole ja mäletan seda, mida sa ütlesid: "Ärge jooge!" Sa palusid seda, sest ma pidin pärast pidu sõitma. Seega jõin ainult limpsi. Ma olin enda üle uhke, sest järgisin nõu. Vastupidi kui sõbrad, ma tegin õige valiku.

11 2012. aasta oktoobris osalesin koolipärimuse välitöödel Hiiumaal. Suulistes intervjuudes esitasin küsimusi ka ahelpostitamise kohta. Mitmel korral vastasid keskastme tüdrukud tagasivaatavalt, et mõned aastad tagasi, nooremana, saatsid nad kirju edasi, sest uskusid käsu eirajale osaks langevat ähvardust. Rõhutati, et "praegu, vanema ja kogenumana sellesse enam ei usuta". 
Kui pidu läbi, läksid kõik auto peale, kuigi nad ei olnud sõiduvalmis. Ma teadsin, et mina olen kaine. Ema, ma ei suutnud ette kujutada, mis mind ees ootas... Nü̈̈d magan asfaldil ja kuulen, kuidas politseinikud räägivad... Veri on mööda asfalti ja ma pü̈̈an kõigest jõust mitte nutta... Kuulen, kuidas arstid ütlevad, et ma ei tule sellest välja... Ma olen kindel, et see teine sõber, kes sõitis, ei arvanud, et sõidab nii kiiresti. Lõppude lõpuks, tema oli otsustanud juua ja mina pean nü̈̈d surema. Miks nad teevad nii, ema?!?! Kuigi teavad, et hävitavad elusid.

Valu, mida tunnen, on nagu oleks mind löödud mitme noaga.

Ütle õele, et ta ei kardaks, ja isale, et ta oleks tugev. Keegi oleks pidanud ütlema sellele sõbrale, et ei tohi juua, kui kavatseb sõita. Kui tema vanemad oleksid hoiatanud teda nagu sina mind, oleksin ma veel elus. Hingamine muutub üha nõrgemaks ja mind hirmutab see, ema. Need on minu viimased hetked ja ma olen nii meeleheitel! Tahaksin nii kallistada sind ja öelda sulle, kui palju ma sind armastan... Ma armastan sind, ema... Hüvasti...

Need sõnad kirjutas üks ajakirjanik, kes oli õnnetuspaigal kohal.

Tüdruk sosistas need sõnad enne oma surma ja vapustatud ajakirjanik pani need kirja. Sama ajakirjanik alustas kampaaniat joobes liiklemise vastu. Kui sa seda postitust loed, kuid ei avalda seda või kustutad selle, kaotad võimaluse, isegi kui sa ise ei joo ja Sind see ei puuduta, annad teistele mõista, et sinu elu on ohus...

Ole hea, kopeeri see ja avalda oma seinal!

Digitaalfolkloori uurija Trevor J. Blank (2009, 9) on rõhutanud, et kui suuliselt levivad narratiivid töötavad koodina, mille abil kanaldada sotsiaalseid hirme ja eelarvamusi, siis anonüümsed elektroonilised kirjalikud lood tagavad tunnete väljendamiseks veelgi lihvituma vormi. Liiklusega seotud hirmudega on tänapäeva inimene silmitsi lapsest peale, ka joobes sõidukijuhtide põhjustatud liiklusõnnetused ja surmateema on meediauudistes igapäevane reaalsus, mis jõuab noorte infovälja.

Tõsimeelsete, nt pedofiilide, varaste ja kelmide eest hoiatavate (anonüümsete) kirjade jagamine võib sotsiaalmeedias niivõrd suureks paisuda, et külvab inimestes enda ja oma lähedaste turvalisuse pärast asjatut muret ja paanikat (vt nt Jaagant 2013). Konkreetse paanikakampaaniana võib nimetada nt veebruaris 2013 Facebookis lahvatanud hoiatust mehe kohta, kes Viimsi kooli lähedal bussipeatuses seisnud last enda juurde autosse kutsus ja mille paikapidavust politsei tõsiselt kontrollis (Jaagant 2013). Pealtnäha väga tõsimeelsete hoiatuskirjade levikut võivad tihtipeale toetada ja nagu kuulujuttu võimendada päriselt aset leidnud üksikud (traagilised) 
päevasündmused. Kui 2012. aasta märtsis vapustas Eesti avalikkust 9aastase tüdruku Varvara mõrv Narvas ja kurjategija pole aasta hiljem artikli kirjutamise ajal veel avastatud, siis on selliste hoiatuste levik ja võimendumine nii (lapsevanematest) täiskasvanute kui ka noorte hulgas mõistetav ja põhjendatud. Eelmise allrühma postitustega võrreldes konkreetset sündmust otsesõnu ei nimetata, kuid foonil on see olemas. Sotsiaalmeedia olemus ja ahelpostituse vorm koos kommenteerimise võimalusega sobib hirmude kanaldamiseks vägagi hästi, kuid võib sündmusest endast liikuda väga kaugele ning narratiivsete variatsioonide ja liialdustega kutsuda esile ka kogukonnaliikmete paanika.

\section{Loomadest hoolimine}

Inimeste ja loomade suhetele tänapäeva ühiskonnas viitavad loomadega seotud postitused, milles kutsutakse üles kaasa tundma endast nõrgematele (nt haigetele, kodututele loomadele) ja empaatiliselt tegutsema. Paljudel (linna)lastel on kokkupuuteid lemmikloomadega, loomapidamisega kaasnevat suurt vastutust rõhutatakse nt alljärgnevas ASCII-sümbolitest moodustatud loomakujutistega postituses.

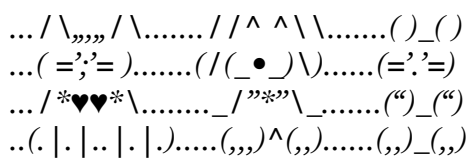

Pane like ja postita see oma seinale, kui sa ei viska kunagi koduloomi tänavale ja hoolid oma loomast!

ASCII- ehk märgikunsti, mille tulemuseks on mitmetest tähtsümbolitest moodustatud piltkirjad, võib Facebooki ahelkirjades kohata sageli.

Mõnikord koosnevad kirjad lugudest ja väidetest, mis on lähedased linnamuistenditele ja hirmulugudele ning eeldavad tõsist uskumist, kuid mille tõelevastavus on vägagi kaheldav. Toon siinkohal näiteteksti, milles kirjeldatakse tõsiseltvõetava traditsioonina kasside kohtlemist Hiinas - nii geograafiliselt kui ka kultuuriliselt kauges piirkonnas - ja võimendatakse üht etnotsentrilist stereotüüpi.

A: Hiinas on lubatut tappa loomi! Naised tulevad ja filmivad kuidas nad kiisusi tapavad! Enne peksavad kiisut ja siis võtavad enda 
kontsakingad, ning enne viskavad kontsaga kiisule peasse ja siis kõhtu. Kiisu nutab aga naised naeravad! Pärast Kass ei kannata ja sureb! Ma ei saa aru mis inimestel viga on!!! :( Kellel on minuga sama arvamus pange like ja postita see ka enda seinale!!!

B: Jube.

A: : (

C: Jube ja minu jaoks täiesti lubamatu!:( Tekib küsimus, kas hiinlased muidu ei saa?!:( Loom on inimese ees täiesti abitu ning minu meelest on hiinlastest lihtsalt jõle ja südametu seda sel otstarbel ära kasutada!:( Mida see neile annab?!:( Ei hakka seda oma seinale kopeerima, sest (ma ei taha sellega midagi halba öelda) see ajab mul südame pahaks ning pisarad kipuvad vägisi silma, aga ma tahaksin kogu südamest, et selline asi lõpeks ja seda ei tee ainult hiinlased! :(

A: JAA... Nõustun

D: Ja see luba tuleks KÕIGILT ära võtta!

D: Aga tore on see, et eestlased kannavad enamasti kontsakingi ikkagi jalas, selle asemel, et neid "pisut" teisel otstarbel kasutada...

A: :D

E: Kui loomi nii edasi koheldakse, (nii seal, kui mujal maailmas) siis võivad inimesed lõpuks lihapallide asemel toataimi sü̈a. Ja kõikidest muudest loomadest ei tasu unistadagi.

E: Aga miks ei võiks karistada neid inimesi, kes loomi kehaliselt väärtkohtlevad? Neid inimesi, kes teisi inimesi kehaliselt väärtkohtlevad, ju karistatakse?

D: Tõepoolest.

Iseäranis huvitav on postitusele järgnenud nelja tüdruku arutelu. Kõik kommenteerijad on ühel meelel, et kirjeldatud loomade kohtlemisviis on taunitav (jube, lubamatu, ajab südame pahaks), pakutakse välja lahendusi (karistada), leitakse isegi positiivset (tore on see, et eestlased kannavad enamasti kontsakingi ikkagi jalas). Kommenteeritav ahelpostitus võimaldab astuda sammukese edasi traditsioonilisest käskudele ja keeldudele tuginevast kasvatusviisist ja kujundada mõttearenduse käigus ühiseid väärtusi.

\section{Kalendritähtpäevade puhul postitatavad sõnumid}

Läheneva tähtpäeva ootusest ja meeldetuletusest annavad ahelpostituse kujul märku tähtpäevaõnnitlused.

Selle temaatilise alaliigi hulgas on populaarsed ahelpostitused, mis esindavad varasematest e-kettkirjadest, e-õnnesoovidest jne tuttavat ASCII-kunsti. ASCII-sümbolid võivad illustreerida igal teemal postitatud sõnumeid, kuid sagedasemad on nt jõuluaeg- 
setele postitustele omased tähtedest ja sümbolitest moodustatud jõulukuused, küünlad või lumehelveste kujutised:

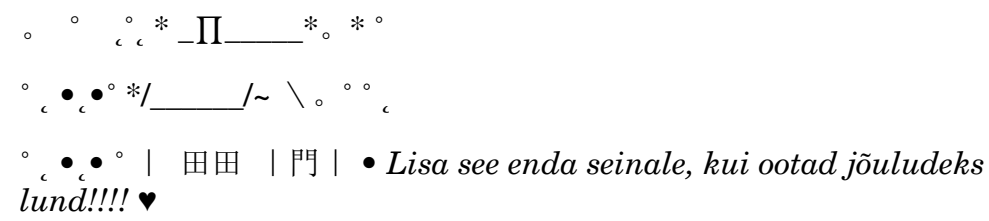

\section{Tähelepanuülesanded ja testid}

Omal kohal on ahelpostituste hulgas tähelepanuülesanded ja erinevad (aritmeetilised, optilised vm) testid, mis on meeleolukad ja panevad proovile vaimsed oskused (nutikuse ja taiplikkuse), kuid pakuvad ka lihtsalt meelelahutust ja lusti. Eesmärkidelt sarnanevad need muude äraarvamisele suunatud dialoogiliste folkloorivormidega, nagu nt mõistatused oma liigilises mitmekesisuses (klassikalised mõistatused, keerdküsimused, piltmõistatused jpt). Üks osa neist nõuab vastust, teine osa on aga pigem anekdoodi funktsioonides vastus on küsimuse järel kirjas ja see moodustab üllatusliku puändi, mis vallandab huumori.

Kui saad sellest sõnumist aru, on sul tugev mõistus.

533 5ÕNUM ON KOO5T4TUD, 3T TÕ35T4D4, M1LL1531D HÄMM45T4V41D JA MULJ3T4V4LD4V41D 45JU 5UUD48 M3I3 MÕ15TU5 T3H4. AL6UL OL1 533 K33RUL1N3, KU1D PR436U LO38 5U MÕ15TU5 5SD4 4UTOM44T5ELT 1LM4 53LL3L3 MÕTL3M4T4. KU1 544D 5ÕNUM15T 4RU, OL3 UHK3 53LL3 ÜL3. M1TT3 KÕ1K 1N1M3S3D 31 5UUD4 53D4 LU63D4.

Pane like, kui said sellest sõnumist aru, ja postita see oma seinale ;D (nb: mitte valetada). Kuna postitasin selle oma seinale, tähendab, et oman head mõistust sellise asja alal. :)

\section{Kettkirjade paroodiad}

Eraldi võib välja tuua ringlevad naljad, mis loodud Facebooki kohta, ütlustest anekdootideni. Nende hulgas leidub mitmeid Facebooki seintele postitatud, varasemast ajast tuntud aforisme ja mõtteteri. Näib, et defineerivad mõtestused koolielu ja elu kohta üldisemalt on igati sobivad, et neid uue lainena sotsiaalmeedias ahelkirjadena levitada. 
Terve hulk ahelpostitusi ongi kettkirjade pilavad jäljendused, mis kannavad ideed, et kogu seda nähtust ei tasu võtta kuigi tõsiselt ega kirjade sisu uskuda, pigem võib seda käsitleda tarbetut müra tekitavate rämpspostitustena. Ka enamasti koomilistes paroodiatekstides on lõpuvormeliks käsk teksti levitada, samuti ähvardatakse ahela katkestajat karistusega, kuid nende tõsiseltvõetavus seatakse hüperboolsete kujundite ja utreeritud ideedega kahtluse alla.

Kopeerige see oma seinale, kui teile käivad tõsiselt närvidele ahelkirjad, nt: kui sa seda kümne minuti jooksul ei kopeeri, siis tuleb ilma näota mees ja kägistab su... FB POLE ELU!

Mõni paroodia seisneb aga kontrastiks kettkirja stiili lõhkumises - absurdihuumorina mõjub nt alljärgnev karistuste nimekiri, mis ootab ees hoopis ahelkirjade postitajat:

Iga kord, kui te kopite mingi sentimentaalse jama oma seinale, siis:

* sureb üks ingel vähki;

* ühel väikesel pingviinil lõigatakse jalad ära;

* üks delfiin sureb kah ära iga kord. hästi nummi delfiin;

* kastreeritakse vähemalt kümme kassipoega;

* lü̈̈akse viiel hülgepojal mõla läbi kolba;

* kaks pandat läheb šašlõkiks;

* hakkab vähemalt üks sõber su sõbralistis sind lolliks pidama.

Parodeerivat ideed ja suhtumist tõsimeelsetesse ahelpostitajatesse annavad edasi nt järgmised postitused:

Kui ... oled alati olnud see debiil, kes igat jama oma seinale lisab, lisa ka see enda staatuseks.

Mõni paroodia mõjub oma metafoorikaga filosoofilise mõttemõlgutusena, mis peaks analoogselt aforismide ja defineeriva ütlusfolklooriga tegevuse üle tõsisemalt mõtlema ärgitama.

Facebook on vaimuhaigla ja me kõik oleme patsiendid. Istume ja vahime ekraani üksi vaikselt naerdes ja kujutame ette, et oleme sotsiaalsed. Mõnel on fantaasiafarmid, -linnad, -loomad ja muud asjad. ME müksame üksteist ja meie arust on see OKEI, kirjutame isegi seintele. Kui sa oled samuti siin ravil, siis kripselda see oma seinale! Varastasin selle sõnumi teiselt patsiendilt! :D

Paroodia võib mõne näitejutu varal ka otsesõnu välja öelda, et keti katkestajaga ei juhtu midagi. 
Üks tüdruk oli oma toas arvutis Facebookis. Ta nägi ühte kirja, kus oli kirjas: "Kui sa ei kopeeri seda, siis sured homme!" Tüdruk ei kopeerinud seda oma seinale ja kas sa tead, mis temaga juhtus? MITTE MIDAGI! Kopeeri see, kui sa neid kettkirju vihkad!!

Pilkealuseks osutub enamasti kettkirjandus, kuid mõnikord võidakse ahelpostituse vormis pilada ka muid žanre. Konkreetset taustatundmist vajab nt alljärgneva kettsõnumi "Pastakas on kirjutusvahend" mõistmine:

\section{Tsau laps!}

Kas sina oled üks nendest, kes ei kanna ise pastakat kaasas? Ömm laenaks nagu teiselt? Mhmhmmm!!! Misasja?? See on sinu otsus, mina ei annaks mitte ühelegi "uuele õpilasele" enda pastakat, miks peaksid seda tegema sina? Pastakas on reaalselt ja tegelt ka, ainus asi millega laps kirjutab. Kas tead, mitu protsenti Eesti lastest pastakat kaasas kannab? Mina igatahes ei tea, aga mis sul ometi viga on? Kui teemaks tulevad pastakad, siis jäta see meelde, tao endale pealuu sisse ja kirjuta ka oma seinale, et PASTAKAS ON KIRJUTUSVAHEND!!

Ilmselgelt on tegemist 2011. aasta sügisel Tervise Arengu Instituudi HIV ennetuskampaania "Kumm on seks" pilkejäljendusega. Mäletatavasti põhjustas originaalreklaam meedias ja üldsuses palju vastukaja, sünnitades terve hulga mitmesuguseid tekstilisi ja videoparoodiaid. Nagu näha, on üheks pilaversiooniks sobinud ka Facebooki ahelpostituse vorm.

Suur osa ahelpostitustest on rahvusvahelised ja enamasti ingliskeelsete samalaadsete seinapostituste tõlked. Vaid mõnel korral olen kohanud eesti laste ahelpostituste hulgas ingliskeelseid, enamasti on need hakanud eestikeelsetena levima ja mõnikord võidakse neisse teha lokaalseid lisandusi. Et noored on etnilise identiteedi otsingutes kultuurilistele ja keelelistele mõjudele väga avatud (Tammemägi, Ehala 2012, 243), siis on tõlgitud emakeelsete tekstide levik kui kirjalik argitraditsioon kasulik keele jätkusuutlikkusele (kuigi teismeline saab aru ka ingliskeelsest postitustest ja võiks samahästi säilitada ja edastada originaalversiooni). Samas tuleb tunnistada, et tõlgitud ahelpostituste keel on tihtipeale kohmakas ja toores. Ingliskeelne arvutiterminoloogia on põhjustanud paljude sõnade, nt kopi (kopeeri), peisti (kleebi, postita), otsemugandumist eesti keelde, Facebooki tehniline süsteem aga lausa nõuab sõnade laigi (like - näita, et meeldib) ja šeeri (share - jaga) jt kasutamist. 


\section{Kokkuvõtteks}

Mõndapidi pole midagi uut siin päikese all. Kettkirjade traditsioon on teisenedes kandunud minevikust tänapäeva. Paljud Facebooki ahelpostituste vormielemendid ja sisumotiivid leiduvad varasemates folkloorikirjapanekutes, nende alged on tuttavad religioosse taustaga (väidetavalt jumala või Kristuse poolt kirja pandud) taevakirjadest, salmi- ja sõbraalbumite traditsioonist või tuntud laste õudus- ja hirmujuttudest, aga ka mitmesugustest naljadest ja folkloori lühivormidest. Samas mõjuvad ahelpostitused, isegi kui neis rakendatakse varasemast traditsioonist tuntud teemasid, struktuurikaanoneid jne, Facebooki keskkonna ette antud tingimustes omalaadse värske traditsioonina, mida tuleb käsitleda tihedas seoses laiema kultuurikontekstiga. Internetikeskkonnas võib neid käsitleda spämmi ehk rämpspostina, kuid vaieldamatult moodustavad nad (nagu ka kett- või ahelkirjad üldse) omapärase argisuhtlemise vormi, mis võib oma igikestvate inimlike teemade, aga ka päevakajaliste meeldetuletustega anda olulist teavet ajastu, keskkonna, kultuuri ja maailmapildi kohta laiemalt. Ahelsõnumid on osa noore postitaja igapäevasest spontaansest persoonibrändist ehk avalikust kuvandist ning pajatavad nii mõndagi tervest pärimusrühmast, kes kirjade saatmist harrastavad, neid vastavalt äranägemisele mõnikord muudavad, oma profiiliseintele postitavad, kirju kommenteerivad, ja sel moel pidevalt suhtlevad. Oma olemuselt toetavad ahelpostitused varateismeliste identiteediloome mehhanisme, neis esinevad teemad (sõprus, romantilised tunded, kodu, perekond, lähedased, lemmikloomad, noori puudutavad šokeerivad ühiskondlikud sündmused jne) toetavad individuaalseid eneseotsinguid ja sotsiaalsete oskuste arengut. Ühtlasi väljendatakse kirjade kaudu kollektiivse identiteedi valdkondi. Identiteedi konstrueerimisel toimivad motivaatorina erinevad tegurid, mis on seotud kujunemiseas noorte enesehinnangu, järjekestvuse, eristumise, kuuluvustunde, enesetõhususe ja tähenduse rahuldamisega.

Ahelepistolaariumi põhjalikum analüüs näitab, et tekstides ilmnevad sageli inimese kui ühiskondliku olendi eksisteerimise seisukohalt olulised ja tähenduslikud väärtused. Need võivad viidata hoolivusele, aususele, sallivusele, õiglusele, elu ja tervise hoidmisele nii noore vahetus suhtlusringis perekonnaliikmete, kui ka koolikaaslastega, virtuaal-ja reaalmaailma sõpruskonnaga, aga ka suhtumistes üleilmsetesse probleemidesse. Eesti hariduses on 
viimasel ajal palju räägitud laste ja noorte väärtuskasvatusest ja väärtuste sihipärasest kujundamisest. Uurija positsioonilt vaadates toimivad ahelpostitused noorte väärtushinnangute indikaatorina, samas toimub postituste kaudu mitteformaalne - argine ja orgaaniline, märkamatu ja loomulik ning noorte endi loodav ja reguleeritav - väärtuskasvatus, millega kujundatakse kõlbelisi arusaamu tihti kooskõlas ühiskonnas üldlevinud arusaamadega, kuid ka neid kahtluse alla seades.

Tänapäeva folkloor on kiiretele muutustele avatud, oma sisuplaanis tihtipeale lühiajaline ja minetab kiiresti aktuaalsuse. Kuivõrd elujõuliseks nähtuseks osutub ahelpostitamise traditsioon ja milliseid arenguid see protsess edaspidi läbib, ei julge ennustada. Küll aga on ilmne, et Facebook oma võimalustega näib olevat sobiv paik sellele kiirelt teisenevale kultuurisidusale folkloorinähtusele.

\section{Kirjandus}

Anderson, Walter 1937. Kettenbriefe in Estland. Eesti Rahvaluule Arhiivi Toimetused 7. Tartu: K. Mattiesen.

Bauman, Richard 1992. Genre. - Bauman, Richard (toim). Folklore, Cultural Performances, and Popular Entertainments: A Communications-centered Handbook. New York, Oxford: Oxford University Press, 53-59.

Ben-Amos, Dan 1997. Genre. - Green, Thomas A. (toim). Folklore. An Encyclopedia of Beliefs, Customs, Tales, Music and Art II. Santa Barbara, California; Denver, Colorado; Oxford, England: ABC-Clio, 409-415.

Bell, David; Loader, Brian D.; Pleace, Nicholas; Schuler, Douglas 2004. Cyberculture: The Key Concepts. London \& New York: Routledge Taylor \& Francis Group.

Blank, Trevor J. 2009. Folklore and the Internet: Vernacular Expression in a Digital World. All USU Press Publications. Book 35. Utah: Utah State University Press (http://digitalcommons.usu.edu/usupress_pubs/35 $-20.03 .2013)$.

Briggle, Adam 2010. Dear Facebook. - Wittkower, D. E. (toim). Facebook and Philosophy: what's on your mind? Popular Culture and Philosophy 50. Chicago and La Salle, Illinois: Open Court, 161-171.

Briggs, Charles L.; Bauman, Richard 1992. Genre, Intertextuality, and Social Power. - Journal of Linguistic Anthropology 2 (2), 131-172 (http://dx.doi.org/10.1525/jlin.1992.2.2.131).

Deci, Edward L.; Ryan, Richard M. 2008. Self-Determination Theory: A Macrotheory of Human Motivation, Development, and Health. Canadian Psychology 49 (3), 182-185 (http://dx.doi.org/10.1037/a0012801). 
Ehin, Kristiina 2003. Naiste identiteedi muutus pärast Esimest maailmasõda - rahvalaul kõneleb. - Pärimus ja tõlgendus. Artikleid folkloristika ja etnoloogia teooria, meetodite ning uurimispraktika alalt. Tartu: Tartu Ülikooli Kirjastus, 158-172.

Frank, Russell 2011. Newslore: Contemporary Folklore on the Internet. Jackson: University Press of Mississippi.

Harter, Susan 1999. The construction of the self: A developmental perspective. New York: Guilford.

Hoppál, Mihaly 2000. Õnnetoov kettkiri: Püha Antoniuse kett linnafolklooris. - Meedia. Folkloor. Mütoloogia. Tänapäeva folkloorist III, lk 322-338 (http://www.folklore.ee/pubte/meedia/kettkiri.html 10.09.2012).

Jaagant, Urmas 2012. Häda sotsiaalmeedias: eestlane läheb alusetu hoiatuse peale paanikasse. - Eesti Päevaleht, 5. märts. (http://www. epl.ee/news/eesti/taismahus-hada-sotsiaalmeedias-eestlane-lahebalusetu-hoiatuse-peale-paanikasse.d?id=65773262 - 20.03.2013).

Kalda, Mare 2004. Siinpool jõge - sealpool jõge. Mõne Emajõe-äärse koha loost. - Mäetagused 27, 73-104 (http://www.folklore.ee/Tagused/ nr27/kalda.htm - 24.01.2013).

Kalmre, Eda 2010. Tüdrukute materjalikogudest ja eneseesitlusest internetis rate.ee päevikute armastusjutustuste näitel. - Kalmre, Eda (toim). Tulnukad ja internetilapsed. Uurimusi laste- ja noortekultuurist. Tänapäeva folkloorist 8. Tartu: EKM Teaduskirjastus, 215-245.

Korb, Anu 2012. Siberi eestlaste kohanemisest ja sulandumisest pärimusainese põhjal. - Mäetagused 50, 47-70 (http://www.folklore. ee/tagused/nr50/korb.pdf - 24.01.2013).

Kress, Gunther 2004 (2. trükk). Literacy in the New Media Age. London ja New York: Routledge (http://dx.doi.org/10.4324/9780203164754).

Krikščiūnas, Povilas 2012. Ėlektronnye pis'ma po cepi: k voprosu o transformacii žanra. - Naučnyi al'manah: Tradicionnaja kul'tura 3 (47), $152-162$.

Kuutma, Kristin 2005-2006. Identiteet. - Jaago, Tiiu (toim). Argikultuuri uurimise terminoloogia e-sõnastik. Tartu Ülikool, eesti ja võrdleva rahvaluule osakond (http://argikultuur.ut.ee - 10.09.2012).

Kõiva, Mare 1993. Õnnel pole hinda. - Koolipärimus. Школьньй фбольклор. Pro folkloristika I, 12-15 (http://www.folklore.ee/era/nt/PF1/1Koiva. $\mathrm{htm}-24.01 .2013)$.

Kõiva, Mare; Vesik, Liisa 2009. Contemporary Folklore, Internet and Communities at the beginning of the 21st Century. - Media \& Folklore: Contemporary Folklore IV, 97-120 (http://www.folklore.ee/ rl/pubte/ee/cf/cf4/CF4_Koiva_Vesik.pdf - 24.01.2013).

Põldmäe, Rudolf 1938. Üks haruldane tüüp eestikeelseist taevakirjadest. - Opetatud Eesti Seltsi Toimetused XXX, 529-537. 
Reich, Stephanie M.; Subrahmanyam, Kaveri; Espinoza, Guadalupe 2012. Friending, IMing, and Hanging Out Face-to-Face: Overlap in Adolescents' Online and Offline Social Networks. - Developmental Psychology 48 (2), 356-368 (doi: 10.1037/a0026980).

Seljamaa, Elo-Hanna 2003. Kettkirjade traditsiooni muutumisest. Taevakirjadest elektronkettkirjadeni. - Hiiemäe, Mall; Labi, Kanni (toim). Teekond. Pro Folkloristica 10. Tartu: Eesti Kirjandusmuuseum, 171-183.

Seljamaa, Elo-Hanna 2004. Dialoogis kettkirjadest. Bakalaureusetöö. Töö asub Tartu Ülikooli eesti ja võrdleva rahvaluule õppetoolis.

Seljamaa, Elo-Hanna 2005. Kettkirjadest folkloristikat ja folkloriste otsimas. - Hiiemäe, Mall; Labi, Kanni (toim). Aega otsimas. Pro Folkloristica 12. Tartu: Eesti Kirjandusmuuseum, 139-150.

Stanley, Liz 2004. The Epistolarium: On Theorizing Letters and Correspondences. - Auto/Biography 12: 3, 201-235 (http://dx.doi. org/10.1191/0967550704ab014oa, http://www.oliveschreinerletters. ed.ac.uk/Epistolariumpdf.pdf - 24.01.2013).

Tajfel, Henri 1978. Differentiation between social groups: Studies in the social psychology of intergroup relations. London: Academic Press.

Tajfel, Henri 1981. Human groups and social categories. Cambridge: Cambridge University Press.

Tammemägi, Anni; Ehala, Martin 2012. Koolinoorte keelehoiakud 2011. aastal. - Keel ja Kirjandus 4, 241-260 (http://kjk.eki.ee/ee/ issues/2012/4/137 - 24.01.2013).

Torop, Peeter 2008. Multimeedialisus. - Keel ja Kirjandus 8, 721-734 (http:// keeljakirjandus.eki.ee/721-734.pdf - 24.01.2013).

Tropp, Kristiina; Saat, Helve 2010. Õpilaste suhted eakaaslaste ning täiskasvanutega ja sotsiaalsete oskuste areng. - Kikas, Eve (toim). Õppimine ja õpetamine esimeses ja teises kooliastmes. Tartu: Haridusja Teadusministeerium, 61-86 (https://www.tlu.ee/files/arts/11337/ \%C3\%95ppi56fdcaad66ae5ef2f6cf3a77ff5d4cbf.pdf - 24.01.2013).

Vahtramäe, Ell 1998. Taevakirjad Siberi eesti asundustes. - Eesti kultuur võorrsil: Loode-Venemaa ja Siberi asundused. Tartu: Eesti Kirjandusmuuseum, 180-194.

Valk, Aune 2003. Identiteet. - Allik, Jüri; Realo, Anu; Konstabel, Kenn (toim). Isiksusepsühholoogia. Tartu: Tartu Ülikooli Kirjastus, $225-250$.

Valk, Aune; Ojamaa, Triinu 2011. Identiteedist ja selle muutumisest väliseesti ühiskonnas. - Rahvuslik Kontakt 4 (212), 21-27 (http:// www.teretere.eu/identiteedist-ja-selle-muutumisest-valiseestiuhiskonnas/ - 24.01.2013).

VanArsdale, Daniel 2007. Chain Letter Evolution (http://www.silcom. com/ barnowl/chain-letter/evolution.html - 24.01.2013). 
Vignoles, Vivian L.; Regalia, Camillo; Manzi, Claudia; Golledge, Jen; Scabini, Eugenia 2006. Beyond self-esteem: influence of multiple motives on identity construction. - Journal of Personality and Social Psychology 90 (2), 308-333 (http://dx.doi.org/10.1037/0022-3514.90.2.308).

Voolaid, Piret 2012. Pane like ja postita oma seinale: Valimik Facebooki ahelpostitusi. Tallinn: Ajakirjade Kirjastus.

Voolaid, Piret; Tuisk, Astrid; Tupits, Ave 2007. Koolipärimus Eestis viisteist aastat hiljem. - Paar sammukest: Eesti Kirjandusmuuseumi aastaraamat 23, 353-362. Tartu: Eesti Kirjandusmuuseum (http:// www.folklore.ee/rl/pubte/ee/araamat/2007/koolip.pdf - 24.01.2013).

\section{Summary}

\section{Chain Posts on Facebook - Identity Construction and Values}

Keywords: chain posts, chain letters, Facebook, identity, Internet folklore, school lore, youth lore, social networking, values, luck chain letters

The article focuses on chain posts that were collected in the years 2010-2012 and spread predominantly among girls of ten to twelve on Facebook (facebook.com) - a social network that has a membership of over 450,000 in Estonia. The source material comprising approximately 220 texts is similar by form and content to chain letters known from earlier tradition; yet, the web environment with its specific technical structure allows the texts to turn into a peculiar Facebook-like phenomenon.

The author takes a closer interest in the changes in form adapted to chain letters as a genre in Facebook environment as well as thematic categories of these letters. The analysis of the epistolary cultural phenomenon focuses on the socio-folkloric nature of texts with its communicative and socio-cultural aspects. The main focus is on how socio-cultural environment influences changes in the genre, what kind of global and local impacts occur in Estonian-language chain posts and how this everyday genre reflects the realities of the era and the values intrinsic to this age group. The levels of personal and collective identity construction of chain posters as a special age group have been analysed against the identity motivation theory known from social psychology. 


\section{MAAILM ja \\ MULTITASKING}

\section{Koostanud ja toimetanud MARE KÕIVA}

http://www.folklore.ee/rl/pubte/ee/cf/multi

ISBN 978-9949-544-01-1

Tartu 2014

Trükis ilmunud:

MAAILM ja MULTITASKING. Tänapäeva folkloorist 10.

Tartu 2014

Sarja peatoimetaja: Eda Kalmre

Kogumiku koostaja ja toimetaja: Mare Kõiva

Keeletoimetaja: Asta Niinemets

Kaanekujundus: Lilli-Krõõt Repnau

Küljendus: Diana Kahre

HTML: Diana Kahre

Trükist toetasid: teadusteema SF 0030181s08, ETF grant nr 8137 ja IUT22-5 ning Eesti Kultuurkapital.

E-raamatu valmimist toetas: EKKM14-344 Eesti keele, kultuuri ja folkloori kasutusalade laiendamine ja tutvustamine elektroonilistel infokandjatel.
(C) Mare Kõiva
(C) autorid
(C) EKM Teaduskirjastus 2014 